\title{
PEMBERDAYAAN MASYARAKAT MELALUI PELATIHAN KOMUNIKASI EFEKTIF BERBASIS POTENSI WISATA DAN KEARIFAN LOKAL
}

\author{
COMMUNITY EMPOWERMENT THROUGH EFFECTIVE COMMUNICATION \\ TRAINING BASED ON POTENTIAL TOURISM AND LOCAL TOURISM
}

\author{
${ }^{1)}$ Aat Ruchiat Nugraha, ${ }^{2}$ Susie Perbawasari, ${ }^{3)}$ Feliza Zubair, dan ${ }^{4}$ Evi Novianti \\ 1,2,3,4) Program Studi Hubungan Masyarakat \\ Fakultas Ilmu Komunikasi Universitas Padjadjaran \\ J1. Raya Bandung-Sumedang Km.21 Jatinangor 54363 \\ Email: ruchiat@unpad.ac.id
}

\begin{abstract}
ABSTRAK
Untuk membangun pola komunikasi yang terus berkelanjutan dalam hal kepariwisataan, masyarakat perlu dirangsang melalui program skema komunikasi pemberdayaan pada kegiatankegiatan yang terkait dengan event pariwisata, seperti pelatihan komunikasi efektif. Program pelatihan komunikasi efektif tentang kepariwisataan dilakukan berdasarkan potensi keragaman pariwisata yang terdapat di desa Bongas kecamatan Cililin yang memiliki adat, tradisi, budaya dan seni lokal. Pelatihan ini bertujuan memberikan pengetahuan dan keterampilan secara lisan dan tulisan yang dihadapi oleh masyarakat dalam menyampaikan pesan kepariwisataan ke pihak luar. Pendekatan kegiatan pelatihan ini menggunakan metode ceramah, diskusi, dan simulasi dengan peserta berasal dari pelaku UMKM dan kelompok sadar wisata. Hasil kegiatan menunjukkan adanya peningkatan pengetahuan dan pemahaman peserta terhadap pentingnnya komunikasi efektif dalam bentuk pengemasan pesan beserta teknik publikasinya bagi pelaku UMKM dan kelompok sadar wisata di desa Bongas. Kesimpulan kegiatan pengabdian kepada masyarakat ini adalah bahwa potensi keragaman pariwisata akan semakin terkelola dengan baik apabila dilakukan dengan penyampaian pesan secara efektif mengenai objek wisata ke masyarakatmelalui skema pemberdayaan masyarakat yang partisipatif
\end{abstract}

Kata kunci : Potensi Pariwisata, Komunikasi Efektif, Pemberdayaan Masyarakat

\section{ABSTRACT}

In order to establish a continuous pattern of communication in terms of tourism, the community needs to be stimulated through empowerment communication schemes in activities related to tourism events, such as effective communication training. Effective communication training programs on tourism are based on the potential of tourism diversity in the village of Bongas, Cililin sub-district which has local customs, traditions, culture, and art. This training aims to provide knowledge and skills verbally and in writing faced by the community in conveying tourism messages to outsiders. The approach to this training activity uses lecture, discussion and simulation methods with participants coming from UMKM actors and tourism conscious groups. The results of the activity showed an increase in participants' knowledge and understanding of the importance of effective communication in the form of message packaging along with its publication techniques for UMKM and tourism-aware groups in the village of Bongas. The conclusion of this community service activity is that the potential for tourism diversity will be better managed if carried out by delivering messages effectively about tourism objects to the community through participatory community empowerment schemes.

Keywords: Tourism Potential, Effective Communication, Community Empowerment

Submited : 28 Oktober 2018

Revision : 3 Januari 2019

Accepted : 16 Januari 2019 


\section{PENDAHULUAN}

Kabupaten Bandung Barat sebagai salah satu kabupaten di Jawa Barat yang memiliki daerah topografi eksotis karena wilayahnya yang bergunung, memiliki bendungan, dan dikelilingi oleh kawasan purba yang berpotensi untuk diberdayakan secara alam maupun sosial budaya untuk menjadi modal kegiatan pariwisata. Keberadaan sektor pariwisata dapat menjadi sektor unggulan pendapatan bagi pemerintah kabupaten dalam upaya memenuhi pembiayaan pembangunan infrastruktur dan suprastruktur yang ada di suatu wilayah. Sehingga capaian sektor pariwisata dapat dioptimalkan apabila terjadi koordinasi yang baik antarsektor yang dimiliki oleh suatu daerah tersebut.

Dalam rangka mencapai sasaran pembangunan kepariwisataan di wilayah kabupaten Bandung Barat tentunya harus disesuaikan dengan permasalahan yang terdapat di suatu kawasan wisata. Salah satu permasalahan dalam pengembangan objek pariwisata adalah sering tidak komunikatifnya antarsektor yang mendukung terwujudnya pembangunan pariwisata yang berkelanjutan di suatu daerah. Padahal, pelaksanaan pembangunan sektor pariwisataharus merujuk pada Undang-Undang Nomor 10 Tahun 2009 tentang Kepariwisataan yang mengamanatkan bahwa salah satu tujuan kegiatan kepariwisataan adalah upaya melestarikan alam, lingkungan dan sumberdaya dengan berlandaskan pada prinsip-prinsip memelihara kelestarian alam dan lingkungan hidup, memberdayakan masyarakat setempat dan menjamin keterpaduan antarsektor, antardaerah, antara pusat dan daerah yang merupakan satu kesatuan sistemik dalam rangka otonomi daerah serta keterpaduan antarpemangku kepentingan. Sehingga untuk mencapai sasaran pembangunan pariwisata secara tepat harus dapat melibatkan berbagai masyarakat dalam rangka meningkatkan kualitas kesejahteraan di daerah pariwisata. Sebagaimana hal ini dikemukan oleh (Rustanto, 2016) yang menyatakan bahwa pemberdayaan merupakan suatu kegiatan untuk meningkatkan kepercayaan, peluang, dan kinerja warga minoritas untuk mencegah dan mengatasi masalah yang ada dilingkungannya. Maka, terkait dengan pengembangan potensi pariwisata, pola pemberdayaan di masyarakat dirasakan sangat cocok dalam mendukung proses pembangunan pariwisata yang berkelanjutan, khususnya di desa Bongas kecamatan Cililin kabupaten Bandung Barat.

Seiring dengan pembangunan objek pariwisata yang digalakan oleh pemerintah yaitu harus melibatkan peranan komunitas yang terdapat dalam kawasan yang akan dijadikan sebagai objek wisata. Secara konseptual prinsip dasar kepariwisataan berbasis masyarakat adalah menempatkan masyarakat sebagai pelaku utama melalui pemberdayaan masyarakat dalam berbagai kegiatan kepariwisataan, sehingga kemanfaatan kepariwisataan sebesar-besarnya diperuntukkan bagi masyarakat. Sasaran utama pengembangan kepariwisataan haruslah meningkatkan kesejahteraan masyarakat (setempat). Lebih lanjut, mengenai konsep pelibatan komunitas atau Community Based Tourism (CBT) lazimnya digunakan oleh para perancang pembangunan pariwisata memobilisasi komunitas tertentu untuk berpartisipasi secara aktif dalam mengembangkan objek wisata sebagai rekan industri pariwisata.

Apabila melihat trend dunia global saat ini pengembangan CBT telah dibakukan sebagai alat dan strategi pembangunan tidak hanya terbatas di bidang pariwisata, melainkan dalam konteks pembangunan negara, dengan membuka kesempatan dan akses komunitas untuk berpartisipasi dalam proses 
pembangunan di berbagai sektor seperti kesehatan, pendidikan, dan infrastruktur. Melalui proses pembangunan yang dilakukan oleh negara, tiada lain bertujuan untuk meningkatkan ketersediaan serta perluasan distribusi kebutuhan hidup masyarakat agar berdaya. Melihat potensi CBT yang ada di kabupaten Bandung Barat yang tersebar cukup banyaktentunya perlu digali dan dimanfaatkan secara efektif dan efisien agar dapat menunjang pembangunan dan pertumbuhan ekonomi di wilayah kawasan pariwisata. Melalui teknik pemetaan CBT yang ada di masyarakat kabupaten Bandung Barat sesungguhnya dapat mempermudah bagi para pemangku kepentingan pariwisata untuk mengembangkan berbagai potensi wisata kearah yang lebih profesional dalam aspek pengelolaannya sehingga dapat berdaya secara maksimal.

Membahas tentang pemberdayaan masyarakat biasanya berhubungan dengan tingkat kesiapan masyarakat dalam upaya meningkatkan nilai kualitas hidup secara berkelanjutan. Yang dimana dalam konsep pemberdayaan, masyarakat bukan hanya sekedar menjadi objek pembangunan saja melainkan juga sebagai subjek yang mensukseskan pelaksanaan pembangunan. Oleh karena itu, kegiatan pariwisata yang mengandalkan pada aspek pemberdayaan akan terkait dengan masalah-masalah sosial-budaya yang dianut oleh masyarakat itu sendiri, sehingga sebagai upaya masyarakat untuk mensinergikan pemberdayaan di suatu wilayah biasanya diperkuat dengan nilai-nilai lokalitas yang mewujudkan keharmonisan yang telah menjadi nilai kearifan lokal dalam kehidupan berkeluarga.

Fenomena inilah yang dialami oleh masyarakat kabupaten Bandung Barat dalam upaya mengembangkan potensi pariwisata yang terkait dengan nilai kearifan lokal dikarenakan masih minim dalam hal publikasi ke para wisatawan.
Kurangnya nilai publikasi dapat menjadi hambatan tersendiri serta dapat memberikan dampak pada kurang bergaungnya tempat-tempat pariwisata di kabupaten Bandung Barat, yang dimana masyarakat mengenal kawasan wisata Bandung Barat adalah Lembang dan sekitarnya saja. Padahal, apabila ditelaah lebih rinci lagi, kawasan Bandung Barat sangat kaya akan potensi wisata yang dapat menghasilkan pendapatan yang menguntungkan bagi masyarakat, pemerintah dan pengelola jika informasi nilai kepariwisataannya terkomunikasikan dengan baik.Sehingga pengkomunikasian daerah pariwisata Bandung Barat seharusnya dilakukan oleh berbagai kelompok kepentingan agar "branding" pariwisata Bandung Barat dapat dikenal dengan mudah oleh masyarakat.

Desa Bongas yang merupakan bagian dari kecamatan Cililin sebagai daerah yang berada di kawasan peralihan antara daerah pegunungan dengan daerah bendungan memiliki beberapa potensi wisata yang dapat menarik perhatian dan pendapatan bagi masyarakat apabila dikelola dengan baik. Saat ini, pengembangan pariwisata di desa Bongas masih mengandalkan pada potensi produk usaha menengah \& kecil masyarakat (UMKM) yang dikembangkan oleh sekelompok masyarakat dengan produknya berupa hasil kerajinan bambu dari industri kreatif yang sedang dirintis.

Berdasarkan latar belakang tersebut diatas, maka dapat dijelaskan bahwa permasalahan yang dihadapi oleh masyarakat di kawasan wisata di kabupaten Bandung Barat adalah teknik penyusunan dan penyampaian pesan yang akan dikomunikasikan ke stakeholders masih dirasakan sangat sulit, tidak memiliki modal, serta terbatasnya akses jalan yang menghubungkan antarobjek pariwisata yang bersifat nyaman bagi wisatawan. Melihat hasil observasi 
lapangan, tim PKM Prodi Humas Fikom Unpad berupaya mengadakan kegiatan pengabdian pada masyarakat dengan tujuan untuk dapat memberikan pengetahuan dan pemahaman bagi masyarakat mengenai pentingnya komunikasi efektif dalam rangka menarik perhatian calon wisatawan dan investor yang akan datang ke kabupaten Bandung Barat. Adapun tujuan kegiatan ini adalah untuk dapat memberikan pengetahuan dan keterampilan di bidang komunikasi efektif bagi masyarakat di wilayah kabupaten Bandung Barat, khususnya di desa Bogas kecamatan Cililin dalam rangka menyusun teknik-teknik menginformasikan dan mempublikasikan potensi-potensi wisata yang dapat menarik perhatian bagi calon wisatawan dan investor yang akan datang ke kabupaten Bandung Barat.

\section{METODE}

Metode pemberdayaan masyarakat melalui pelatihan komunikasi efektif yang berbasiskan potensi wisata dan kearifan lokal di kabupaten Bandung Barat merupakan rumusan yang ideal untuk menghasilkan kualitas masyarakat yang kompetitif. Adapun mitra yang menjadi sasaran dalam pelaksanaan PKM pada kesempatan ini yaitu kelompok UMKM produk Bambu dan tokoh masyarakat yang bergerak di bidang industri kreatif wilayah desa Bongas kecamatan Cililin kabupaten Bandung Barat.

Keberadaan kelompok UMKM Bambu di desa Bongas kecamatan Cililin masih termasuk kategori baru secara legalitas hukum, namun untuk masalah pengalaman di lapangan, UMKM Bambu ini telah eksis cukup lama sekitar 5 (lima) tahun dengan hasil produknya di jual ke daerah Jabotabek, Bandung, dan kota besar lainnya.Dengan prestasi pemasaran yang cukup luas tersebut dapat menjadi dasar bagi tim PKM untuk dapat memberikan suatu pelatihan di bidang komunikasi agar dapat mendukung proses penjualan produk yang selama ini dilakukan secara klasik. Padahal, sekarang sudah memasuki era nya penggunaan dan pemanfaatan teknologi informasi dan komunikasi dalam segala bidang kehidupan, termasuk pada proses pemasaran dan pengembangan pariwisata.

Kegiatan pengabdian masayarakat dilakukan dengan pendekatan workshop, meliputi: 1)Ceramah dan tanya jawab. Metode ceramah digunakan untuk menyampaikan penjelasan kepada peserta; tentang materi terkait pelatihan komunikasi efektif untuk pemberdayaan masyarakat pada organisasi pemuda atau karang taruna.Pada sesi ini jugadisampaikan contoh implementasi praktik komunikasi efektif pada komunikator dan pembuatan isi pesan yang komunikatif, untuk memperjelas gambaran praktik komunikasi efektif kegiatan pada bidang pariwisata yang dibuat oleh peserta. 2) Diskusi dilakukan untuk menggali persoalanpersoalan yang berhubungan denganpraktik komunikasi efektif di bidang pariwisata, serta memberikan pelatihan teknis pembuatan penyusunan event kegiatan yang bernilai. 3) Pendampingan ini bertujuan memberikan pengarahanpadasaat penyusunan event yang dapat mendatangkan potensi wisata.

Untuk evaluasi kegiatan, tim melakukan uji pengetahuan dan keterampilan mengenai konsep dan praktek komunikasi yang terkait dengan pelaksanaan pariwisata dan pengembangan bisnis di wilayah Cililin berupa pretest dan postes.

\section{HASIL DAN PEMBAHASAN}

Komunikasi efektif memiliki peranan dalam meningkatkan kualitas interaksi dan hubungan antarmanusia melalui penyampaian informasi sebagai 
pesan utama. Dengan demikian, intisari komunikasi adalah suatu berita yang digunakan untuk mengembangkan hubungan antarpertemanan dan membangun kepercayaan antarindividu dengan pertemanan seseorang dalam organisasi.

Terkait dengan pelatihan komunikasi efektif, kita perlu merujuk terlebih dahulu mengenai kata efektif. Secara etimologis, kata efektif sering diartikan sebagai upaya untuk mencapai sasaran yang diinginkan, berdampak menyenangkan, bersifat actual dan nyata. Dengan demikian, komunikasi yang efektif dapat diartikan sebagai penerimaan pesan oleh komunikan sesuai dengan pesan yang dikirim oleh komunikator, kemudian komunikan memberikan respon yang positif sesuai dengan yang diharapkan. Jadi, komunikasi efektif terjadi apabila terdapat aliran informasi dua arah antara komunikator dan komunikan dan informasi tersebut sama-sama direspon sesuai dengan harapan kedua pelaku komunikasi (Nurjaman \& Umam, 2012).

Teknik komunikasi efektif yang dilaksanakan dalam program pengabdian kepada masyarakat (PKM) di desa Bongas kecamatan Cililin kabupaten Bandung Barat merupakan suatu hal yang menyenangkan dan mudah untuk dipahami namun biasanya sulit untuk dipraktekkan. Hal ini dapat terjadi karena sebagian besar masyarakat masih "alergi" untuk dapat menyampaikan suatu informasi kepada orang lain. Padahal, isi informasi itu mungkin dapat meningkatkan kesejahteraan melalui perekonomian yang mereka lakukan sehari-hari. Keadaan seperti ini perlu sebuah motivasi yang sesuai dengan program pelatihan. Sebab menurut (Putri, Santika, \& Puspita, 2018) bahwa dalam proses pelatihan yang disisipi dengan materi harus disampaikan dengan hasil yang dapat merubah cara berpikir peserta yang harus ditekankan berupa keinginan untuk belajar, siap belajar, dan alasan tetap mau belajar.

Guna untuk mengetahui efektifitas penyampaian materi yang dilakukan oleh tim PKM Prodi Humas, maka dilakukan uji pretest dan postes. Tujuan dari ujian ini adalah untuk mengetahui sejauhmana proses hasil pembelajaran yang disampaikan oleh pemateri terhadap peserta. Adapun hasil tes pengetahuan mengenai konsep dasar komunikasi efektif adalah sebagai berikut:

\section{Tabel. 1 Hasil Uji Pretest dan Postest}

\begin{tabular}{ccc}
\hline Kegiatan & Pretest & Postest \\
\hline Aspek & 10 Orang & 20 Orang \\
Kognitif & $(50 \%)$ & $(100 \%)$ \\
(Tahu) & & \\
\hline $\begin{array}{c}\text { Aspek Afektif } \\
\text { (Merasa }\end{array}$ & 8 Orang & 15 Orang \\
Perlu) & $(40 \%)$ & $(75 \%)$ \\
\hline $\begin{array}{c}\text { Aspek Konatif } \\
\text { (Dapat } \\
\text { Melakukan) }\end{array}$ & 4 (Orang) & 6 Orang \\
& $(20 \%)$ & $(30 \%)$
\end{tabular}

Sumber: Hasil Olah Data PKM, 2018

Berdasarkan data tabel 1. diatas menunjukkan bahwa secara kuantitatif pengetahuan peserta mengenai komunikasi efektif sebesar $50 \%$ pada awal dilakukan pelatihan. Namun, setelah dilakukan penyampaian materi pengetahuan peserta meningkat dua kali lipat yaitu sebesar $100 \%$ mengenai ruang lingkup komunikasi efektif. Untuk aspek afektif, posisi hasil pretest menunjukkan sebesar $40 \%$, yang artinya peserta masih menganggap bahwa pelatihan komunikasi efektif tersebut sebatas kegiatan tambahan dalam penyelenggaraan kegiatan pengembangan pariwisata dan produk UMKM. Setelah penyampaian materi, nilai postest yang dihasilkan cukup signifikan meningkat sebesar $75 \%$ yang menyatakan bahwa perlu dilakukan pelatihan komunikasi efektif dalam rangka menguatkan proses pemasaran pariwisata yang ada di wilayah kecamatan Cililin dan sekitarnya. Sedangkan untuk penilaian pretest 
mengenai aspek konatif, nilai peserta hanya $20 \%$ yang menyatakan bisa melakukan kegiatan komunikasi efektif. Sedangkan $30 \%$ hasil postest menunjukkan ada peningkatan yang tidak begitu besar dikarenakan kemampuan peserta dalam mempraktekkan komunikasi efektif dalam bentuk verbal (berbicara di depan umum/presentasi) masih sedikit yang bisa melakukannya. Begitu juga dengan komunikasi efektif dalam bentuk nonverbal (berupa pembuatan pesan di media visual) belum pada bisa dikarenakan keterbatasan pengetahuan teknik komputer yang mendukung pembuatan media-media komunikasi yang bersifat menarik bagi khalayak sasaran.

Untuk mendapatkan hasil yang baik dalam pelatihan komunikasi efektif yang disampaikan kepada peserta diawali dengan penyampaian materi dengan metode ceramah. Metode ini dipilih dengan alasan karena pendekatan pendidikan, proses timbal balik yang diharapkan akan terbentuk dengan cepat apalagi ditunjang dengan media visual berupa power point.

Jumlah peserta yang hadir dalam kesempatan pelatihan ini berjumlah 20 orang dari undangan yang direncanakan sebanyak 30 orang. Hasil pelatihan ini menunjukkan ada peningkatan pengetahuan dan keterampilan menyampaikan pesan verbal khususnya.

Sebelum pelatihan komunikasi efektif ini dilaksanakan peserta masih merasa malu-malu untuk dapat tampil di depan orang banyak. Namun, setelah diberikan tips dan trik agar tidak gugup tampil di depan umum peserta menjadi lebih percaya diri lagi dalam menyampaikan informasi-informasi terkait bisnis industri kreatif maupun potensi pariwisata yang ada di lingkungan sekitar kecamatan Cililin.

Dalam penyampaian materi mengenai pemetaan potensi wisata agar dapat dimanfaatkan sebagai bagian dari upaya pemberdayaan masyarakat, menunjukkan bahwa motivasi peserta meningkatkan mengenai pengetahuan dan keterampilan kelompok UMKM dalam upaya memperkenalkan ekonomi kreatif di kawasan Cililin dan sekitarnya. Hal ini dapat dibuktikan dengan beberapa pernyataan dari peserta yang ingin memiliki kemampuan memasarkan secara online produk-produk kerajinan bambu yang berasal dari para pengrajin di sekitar kecamatan Cililin. Selain itu, tingkat literasi peserta mengenai pohon Bambu menjadi meningkat dengan lebih menghargai dan menjaga kelestarian pohon Bambu bukan hanya sekedar sebagai pohon biasa saja. Akan tetapi, dianggap sebagai pohon yang bernilai ekonomis tinggi.

Terkait dengan kontribusi lembaga pemerintahan, para peserta menjadi lebih termotivasi kembali untuk dapat bekerjasama dengan Dekranisda Kabupaten Bandung melalui penataan dan penyusunan pesan yang memiliki nilai jual ke pihak investor. Yang dimana selama ini, pengrajin Anyaman Bambu yang terdaftar di Deskrada adalah yang ada di desa Tanjung Wangi kecamatan Cihampelas. Padahal, hasil produk anyaman Bambu dari kecamatan Cililin tidak kalah hasil kualitasnya dibandingkan dengan kecamatan Cihampelas. Hal ini dapat terjadi karena para pengrajin anyaman bambu di kecataman Cililin sangat jarang mendapatkan pelatihan-pelatihan yang dapat meningkatkan pengetahuan maupun motivasi dalamrangka menunjang pengembangan dan pemberdayaan masyarakat di bidang sosial budaya.

Selain membidik peningkatan motivasi bagi para pengrajin, penyampaian materi lainnya mengenai analisis potensi pengembangan pariwisata di wilayah kecamatan Cililin, khususnya peserta yang berasal dari anggota UMKM dan 
kelompok sadar wisata, telah dapat mengiventarisasi pemetaan potensi wisata untuk dikomunikasikan ke masyarakat luas. Rencana penyampaian komunikasi yang akan dilakukan berupa publikasi di media internal yang terdapat di desa-desa berupa pamphlet maupun posters yang didesain secara multiwarna untuk menghasil kesan enak dilihat (eye catching) oleh semua pihak.

Untuk lebih menguatkan motivasi keseriusan dalam pengelolaan potensi wisata, anggota UMKM dan kelompok sadar wisata akan menyiapkan alternatif media kreatifitas lainnya yang digunakan dalam mengkomunikasikan potensi wisata yang ada di kawasan wisata Cililin dan sekitarnya. Media komunikasi kreatif tersebut dengan cara mengikuti event-event yang diselenggarakan oleh pihak pemerintah maupun swasta terkait dengan usaha ekonomi kreatif dalam rangakaian festival budaya maupun pariwisata.

Mengeanai pelatihan komunikasi efektif pada bidang pariwisata untuk pemberdayaan masyarakat di desa Bongas kecamatan Cililin kabupaten Bandung Barat diisi dengan materi yang sesuai dengan tema. Materi-materi yang disampaikan kepada peserta meliputi unsur-unsur komunikasi dan komunikasi bermedia. Masing-masing anggota tim saling melengkapi dalam penyampaian materi. Lokasi yang digunakan untuk kegiatanpelatihan komunikasi efektif adalah di kampus SMK Muslimin kecamatan Cililin. Pelatihan komunikasi efektif dibagi menjadi tiga kegiatan, yaitu ceramah dantanya jawab tentang komunikasi efektif dan pemberdayaan masyarakat, pelatihan teknis penyampaian komunikasi efektif, dan pendampingan dalam penyusunan agenda kegiatan yang bernilai wisata. Metode pertama dilaksanakan pada hari Sabtu, 18Agustus 2018. Acara dimulai pada pukul 09.0013.00 WIB dan diawali dengan penyampaian sambutan dari ketua timpengabdi yaitu Aat Ruchiat Nugraha, M.Si. Dalam sambutannya, ketuatim pengabdian menyampaikan apresiasi yang luar biasa kepada peserta karena antusiasme dan keaktifan mereka pada acara yang diselenggarakan oleh tim pengabdian masyarakat dari Universitas Padjadjaran. Selain itu juga, disampaikan harapan untuk dapat melanjutkan kerjasama dengan kelompok masyarakat yang ada pada kesempatan mendatang, baik dalam bentukpelatihan maupun bentuk kajian keilmuan dan keterampilan lainnya.

Setelah pembukaan dan sambutan selesai, acara dilanjutkan dengan pemaparan materi oleh tim PKM dosen. Pada akhir sesi diadakan tanya jawab dan sharing dengan peserta mengenai kesulitankesulitan dan pengalaman yang pernah dialami peserta dalam hal pengembangan pemasaran pariwisata terkait kerajinan bambuyang telah berjalan cukup lama. Permasalahanpermasalahan tersebut dikaji dan dibimbing oleh tim pengabdi untuk dicari solusinya.Kegiatan kedua, tim pengabdi memberikan pelatihan teknis komunikasi efektif pada kegiatan pariwisata yang berbasiskan nilai lokal. Para peserta dibagi menjadi beberapa kelompok.Kemudian tim pengabdian meminta kelompok-kelompok peserta untuk mencari dan menemukan ide kegiatan yang akan disampaikan dalam komunikasi efektif, terutama terkait dengan story telling mengenai potensi wisata di kawasan Cililin dan sekitarnya.

Kegiatan pengabdian kepada masyarakat dilaksanakan sesuai dengan rencana yang telah ditetapkan. Peserta juga mengikuti kegiatan hingga selesai. Mereka terlihatantusias dan menyimak materi yang disampaikan oleh tim PKM. Beberapa peserta mengajukan pertanyaan terkait materi dan permasalahan-permasalahan 
yang munculdi dalam upaya melaksanakan kegiatan pariwisata yang berbasiskan kerajinan bambu. Antusiasme peserta terhadap tema dan materi yang disampaikan juga terlihat dari kehadiran peserta yang mencapai 20orang. Hal ini menunjukkan ketertarikan peserta terhadap materi yang disampaikan. Peserta juga mengikuti keseluruhan kegiatan, baik sesi pertama, kedua,dan terakhir dengan sangat antusias.

Pelatihan komunikasi efektif bagi masyarakat pedesaan bukanlah sesuatu yang mudah untuk dapat menikmati hasilnya karena dibutuhkan latihan yang terstruktur sesuai dengan kebiasaan dan kemampuan masyarakat dalam bersosialisasi dengan masyarakat lainnya. Kegiatan komunikasi ini seharusnya sudah menjadi bagian dari pengembangan informasi masyarakat pedesaan yang masih memegang teguh terhadap pola guyub. Dengan adanya pola guyub sebenarnya membantu bagi individu untuk terus menyampaikan ide gagasan dalam upaya mempengaruhi keterampilan seseorang untuk bisa berdaya. Setelah penyampaian materi, peserta dibebani untuk membuat pemetaan potensi wilayah Cililin dan sekitarnya yang dapat dijadikan destinasi wisata baru yang bermanfaat bagi peningkatan kesejahteraan masyarakat sekitar.

Kegiatan ini sekaligus mendorong semangat bagi masyarakat yang memiliki potensi kewirausahaan untuk tidak pantang menyerah dan selalu kreatif menemukan ide baru terkait upaya pemasaran hasil kerajinan yang bersifat home industry. Hal ini dilakukan dengan menyajikan materi mengenai konsep pemberdayaan sebagai suatu konsep alternatif pembangunan yang pada intinya menekankan pada otonomi dalam pengambilan keputusan dari suatu kelompok masyarakat berlandaskan ontologi dari hakikat sumberdaya pribadi yang bersifat individual melalui interaksi sosialnya. Konsep pemberdayaan dan partisipasi merupakan strategi cukup efektif pada pelaksanaan pembangunan sekarang ini yang bertumpu pada masyarakat (Adimihardja \& Hikmat, 2003). Dalam konsep pemberdayaan manusia ditempatkan sebagai subjek yag dimaknai dalam suatu proses yang mengandung dua kecenderungan. Pertama, proses pemberdayaan menekankan pada proses mengalihkan sebagian kemampuan, kekuatan atau kekuasaan kepada masyarakat agar individu yang belum berdaya menjadikan lebih berdaya agar mencapai kemandirian. Substansi keberdayaan yang ditransformasikan adalah menumbuhkan susunan hakikat kodrat yang ada pada diri manusia terhadap unsur jiwa (akal, rasa, karsa) dalam raganya berbentuk material dan nonmaterialnya. Kedua, proses pemberdayaan masyarakat menekankan pada proses menstimulasi, mendorong agar individu yang belum berdaya mempunyai kemampuan untuk menentukan pilihan hidupnya melalui dialog.

Kedua kecenderungan dalam proses pemberdayaan masyarakat saling terkait, biasanya dimulai dari kecenderungan kedua melalui proses dialog dan kemudian berlanjut pada kecenderungan pertama dalam bentuk transformasi nilai-nilai pemberdayaan. Sehingga memberdayakan anggota UMKM dan masyarakat sadar wisata di wilayah desa Bongas kecamatan Cililin merupakan upaya meningkatkan harkat dan martabat manusia dalam lapisan persaingan ekonomi yang semakin kompetitif. Tujuan pemberdayaan pada pelatihan komunikasi efektif adalah memampukan masyarakat agar menjadi produktif yang dapat berdaya dan mandiri melalui penyampaian pesan yang baik dan bernilai berita.

Hasil analisis tersebut menjadi bukti bahwa usaha pemberdayaan masyarakat perlu dipertimbangkan dalam 
aspek pengembangan kepariwisataan di suatu daerah, khususnya di desa Bongas kecamatan Cililin. Usaha pengembangan kepariwisataan tersebut mencakup seni, budaya dan industri kreatif yang terdapat pada suatu objek wisata, dapat menjadi dayat tarik wisatawan dan calon investor untuk berkunjung sekedar singgah ataupun betul-betul untuk berwisata. Merujuk pada hasil penelitian mengenai pemberdayaan masyarakat bahwa proses pemberdayaan masyarakat dipengaruhi oleh faktor internal berupa self organizing dan faktor luar yaitu proses pendampingan (Safira, Perbawasari, \& Sani, 2018). Maka, terkait dengan pelatihan komunikasi efektif yang dilakukan merupakan bagian dari upaya untuk meningkatkan performance masyarakat mengenai self organizing yang sudah terbentuk yaitu kelompok UMKM dan sadar wisata untuk dapat berperan lebih konsisten lagi dalam proses pembangunan dan pengembangan objek wisata yang ada di daerahnya masingmasing untuk disampaikan ke pihak luar. Melalui komunikasi efektif diharapkan kedepannya masyarakat dapat mengelola potensi pariwisata yang dapat meningkatkan kesejahteraan masyarakat sekitar objek wisata.

Pada akhirnya, hasil pelatihan ini nampak bahwa masyarakat lebih termotivasi untuk dapat mengembangkan kreatifitas anyaman bambu untuk dikemas dalam bentuk pesan yang menyenangkan bagi khalayak sasarannya guna memiliki nilai jual tinggi yang akan berdampak pada proses pengembangan industri rumah tangga anyaman bambu dan produk olahan kerajinan tangan lainnya. Melalui pengembangan indutri kerajinan rumah tangga setidaknya akan memberikan peluang pengembangan pariwisata kreatif di wilayah kecamatan Cililin dan sekitarnya.

\section{SIMPULAN}

Pengetahuan masyarakat desa
Bongas kecamatan Cililin kabupaten
Bandung Barat mengenai komunikasi
efektif masih sebatas mengenal dan belum
tahu bagaimana praktiknya. Sedangkan
implementasi komunikasi efektif yang
dilakukan oleh masyarakat desa Bongas
kecamatan Cililin kabupaten Bandung
Barat dalam upaya mengembangkan
potensi wisata yang berbasiskan kearifan
lokal masih tergantung pada tokoh
masyarakat sebagai juru bicara untuk
menyampaikan kekayaan keragaman
wisata yang ada di setiap wilayahnya.

\section{UCAPAN TERIMA KASIH}

Ucapan terima kasih kami sampaikan kepada Pimpinan Rektorat, DRPMIK, dan Dekanat Fakultas Ilmu Komunikasi Universitas Padjadjaran yang telah memberikan dan memfasilitasi untuk pelaksanaan kegiatan pengabdian kepada masyarakat pada tahun 2018.

\section{DAFTAR PUSTAKA}

Adimihardja, K., \& Hikmat, H. (2003). Participatory Research Appraisal Dalam Pelaksanaan Pengabdian Kepada Masyarakat. Bandung: Humaniora.

Nurjaman, K., \& Umam, K. (2012). Komunikasi \& Public Relations. Bandung: Pustaka Setia.

Putri, I. V. W., Santika, I. D. A. D. M., \& Puspita, K. D. (2018). Pelatihan bahasa Inggris komunikatif untuk kelompok kerja "Serangan Transport" di desa adat Serangan. Jurnal Pengabdian Dan Pemberdayaan Masyarakat, 2(1), 111-119.

Rustanto, B. (2016). Masyarakat 
Multikultur di Indonesia. Bandung: PT. Remaja Rosda Karya.

Safira, A. M., Perbawasari, S., \& Sani, A. (2018). Proses Seleksi Lokasi Pada Program Pemberdayaan Kelompok Sadar Wisata di Kota Depok. Jurnal Penelitian Komunikasi, 21(1), 87100.

https://doi.org/10.20422/jpk.v21i1.20 4

Sudarman, M. (2014). Sosiologi Komunikasi. Bandung: Mitra Wacana Media. 